\title{
Erratum to: Ownership, Narrative, Things
}

\section{Erratum To:}

(C) The Author(s) 2018

D. Cowan, et al., Ownership, Narrative, Things, Palgrave Socio-Legal Studies, https://doi.org/10.1057/978-1-137-59069-5_1

The original version of the book contained an error that has been corrected. The book title in the below reference has been corrected to "Routledge Handbook of Law and Theory".

Cloatre, E. and Cowan, D. (forthcoming), 'Materialities and Legalities: Some Observations', in A. Philippopoulos-Mihalopoulos (ed), Routledge Handbook of Law and Theory, London: Routledge.

The updated original online version for this chapter can be found https://doi.org/10.1057/978-1-137-59069-5_1 